REPORTS

\title{
Ukrainian folklore in Kazakhstan
}

\author{
Natalie Kononenko \\ Modern Languages and Cultural Studies \\ University of Alberta \\ Edmonton, AB, Canada
}

Pavlodar is on the other side of the earth - quite literally. There is a 12 hour time difference between Edmonton, Alberta, Canada, where I live and Pavlodar, Kazakhstan, where I spent a month of my summer. Thus when it is 6AM in Edmonton, it is 6PM in Pavlodar. Getting to Pavlodar takes a full day. I left on the evening of June 15 and, had I made all my connections, I would have arrived on the morning of June 17. Coming home, my travel time, with plane changes, was 23 hours and 45 minutes.

So why go to Pavlodar? Part of it is the adventure of it all. Why go to Penticton when you can go to Pavlodar? Anyone can go to Penticton; Pavlodar is more of a challenge. But it is not just the risk-taking side of my nature that took me to Pavlodar. There were many other reasons. The personal ones revolve around a desire to see Central Asia, to compare the Kazakh steppe to the Ukrainian one and to the Canadian prairies, to learn more about the Turkic world.

Like many Ukrainians born outside of their home country, I had an imagined Ukraine, a constructed and romanticized picture of my homeland that I had formed in my mind and that begged to be compared to the real thing. I have been able to satisfy my desire to see the real Ukraine, having done extensive fieldwork there since a few years after Ukrainian Independence and having travelled to many regions of the country. Unlike many Ukrainians, however, I also had an imagined Central Asia. I am not sure how I acquired this image. Perhaps it was my work on Ukrainian dumy, epics in which Turkic warriors come charging from the steppe. Perhaps it was the time that I spent in Turkey working on my doctoral dissertation. Whatever the cause, I had acquired my imagined Central Asia - and I had never seen the real thing. Thus my curiosity was great.

There were also academic reasons for going to Pavlodar. Many of the villages to the north and east of Pavlodar, villages with names like Khmelnitskoe, were settled by Ukrainians at about the same time that Ukrainians came to Canada. Studying folklore in these villages would do a great deal towards helping me understand Ukrainian folklore in 
Canada. I had learned over my long academic career that comparative work is enormously rewarding. If one can look at a phenomenon such as adaptation to a new setting from more than one perspective, then the insights one gains are multiplied many-fold. So, when the opportunity to do fieldwork in Kazakhstan presented itself, I accepted. I will not pretend that I did not hesitate. I knew that the trip would be difficult and that the circumstances under which I would work would be trying. Later when things went wrong and a money transfer I sent was not accepted, when email failed to function, when I was unable to reach any of my contacts by phone, my doubts about the wisdom of my decision to travel mounted. But I went nonetheless.

The catalyst for the trip was the Second All-Russia Folklore Congress in Moscow, held in February, 2010. A friend talked me into going - then cancelled her trip so that I ended up being the only person from North America at the meeting. But the adventures of that meeting are the topic of another story. Prior to that Congress I had felt that one of my tasks as a scholar was to present the folklore of the Slavic world, specifically Ukraine, in a manner that my Soviet Ukrainian colleagues could not. Soviet ideology dictated a certain interpretation of folklore and allowed collection of only those genres that supported a Sovietapproved world view. Thus genres that might be construed to extol Ukrainian nationalism, such as historical poems or dumy, were taboo and I felt that it was my duty to write about these poems and other historical genres and about the professional minstrels who performed them, which I did.

The Second All-Russia Folklore Congress was not all-Russian by any means. In fact, there were many colleagues from Ukraine and other nation states that had once been part of the Soviet Union. The papers these folklorists, and those from Russia itself, presented were very good. Listening to them I got no sense that something was being left unexplored or that scholars were forcing an interpretation onto their data, as had happened during Soviet times. Their folklore work was of the highest quality. At the same time it became painfully clear that similarly good folklore work was not being done in Canada. People would ask me about the study of Ukrainian and other Slavic traditions in Canada and I had to admit that much of the collecting work here was done by students. The sort of detailed and systematic research that was being done in the post-Soviet world was sadly lacking in Canada. It was this realization that led me to commit myself to Ukrainian Canadian folklore research. 
I started on Ukrainian Canadian fieldwork in the summer of that same year. I headed out to the Peace country of northern Alberta with colleagues from the history department who were documenting the sacred heritage of the Canadian prairies, photographing rural churches that had fallen into disuse and might soon disappear. Working with this group I asked the historical questions that they wanted answered and, for the folklore component, I asked about rituals. I asked about holidays such as Christmas and Easter. I gathered information about weddings and funerals and baptisms. I also did some documentation of material culture, namely embroideries and other textiles, and interviewed collectors of Ukrainian folk art.

My work in Ukrainian Canada was most enjoyable and rewarding, but I knew it could be better still with a comparative dimension. Here too the Second All-Russia Folklore Congress came into play for it was there that I met Alevtina Tsvetkova, a folklorist from Pavlodar Toraigyrov State University. She invited me to join her on a fieldtrip to the Ukrainian villages of Kazakhstan. For her, inviting me was an opportunity to learn about Western approaches. She perhaps also saw a chance to advance her own position at her university by bringing in a prominent scholar from Canada, something that few of her colleagues could do. I know that she wanted to push for more attention to the study of Slavic folklore in a political atmosphere that promoted all things Kazakh at the expense of other nationalities. Bringing in a foreign Ukrainianist would do that and, indeed, my visit did draw attention and I was interviewed on Kazakh television. For me going to Kazakhstan was that chance to go to Central Asia. Academically, the Kazakhstan project was to be similar to my work in Canada: it was to be the collection of ritual information. The comparative part was to include both Canada and Ukraine because my many trips to Ukraine had also produced extensive documentation of ritual. I must thank Tsvetkova for giving me my Kazakh opportunity and I must also commend her for having the courage to invite a woman whom she had barely met to come and live with her for a month. I am also deeply indebted to Mykhailo Paripsa, the head of the Ukrainian organization in Kazakhstan for taking care of the practical and bureaucratic aspects of my visit and doing it well. It was he who issued my letter of invitation, a letter that easily got me a Kazakh visa. Considering the problems I and others have had with visas to Russia, Paripsa's efficiency is much appreciated. It was Paripsa who contacted the Ukrainian cultural organizations in the villages we visited, thus 
laying groundwork for the contacts with officials, the housing, and all the other practical arrangements that we enjoyed as we did our work.

I learned a great deal in Kazakhstan. I learned about ritual processes and adaptation to a new environment, the academic purpose of my trip. I also learned about possible reactions to the post-Soviet world and variation in the creation of new nation-states from old Soviet fabric. I learned about ethnic tensions. I learned about the role that folklore plays in the lives of people no matter who or where they are.

My trip began with official duties. Bureaucracy and proper procedure are very important in Kazakhstan, perhaps as much as they were in the Soviet Union, and this was brought home to me time and again. My flight into Kazakhstan was plagued with problems from delayed take-offs to missed connections and lost luggage. When I finally arrived in Pavlodar I was allowed to rest briefly and then sent to perform bureaucratic chores. I was told I had to register my residence, something that had always been demanded when I travelled to the Soviet Union, but also something I have not had to do in Ukraine since it became independent. After standing in line for a long time to learn that Canadians no longer need a residency permit, my hostess and I went to Pavlodar Toraigyrov State University where I had to pay my respects to a myriad of officials. We went in reverse order, first the various lesser officials and then the higher level dignitaries. After that I went to pay my fees, a process that was in itself a bureaucratic nightmare. I could not simply sign an agreement saying that I would pay a certain price for my transportation and lodging; before I left Canada I had to send a letter from my University, complete with an official signature and a stamp. Since stamps are not part of Canadian bureaucracy, as onerous as it may be, finding something that would pass as a stamp proved to be a challenge. Once stamped, this letter had to go to Kazakhstan in hard copy; a fax would not do and, since registered mail is seldom sent between Edmonton and Pavlodar, this official letter (in three copies) took almost a month to reach its destination, something that made both me and my hosts very nervous. But the letter did arrive shortly before I did and I paid the agreed-upon fees.

The pressure to follow protocol did not end with my day of bureaucratic formalities at the university. In every village we visited I had to check in with the local akim or government head, and I had to pay my respects to every district akim as well. If the akim was not there on the day of my arrival, I had to go back and pay my respects at a later date, even if it interfered with my work, but not following proper 
procedure was not an option. When my trip was over, I had to return to the University for a round of formal farewells, something that I found quite burdensome since I was trying to pack and to make copies of all of my data, but I did get a striking Kazakh robe as a gift at the end of all of the formalities.

The Soviet-like formalities were time-consuming, something that I was painfully aware of since I had only one month to do my work. I also got the uncomfortable feeling that I was constantly under surveillance, that my every move was being watched. This too reminded me of Soviet times. But as unpleasant as the formalities may have been, they did have their benefits. Because the whole trip was quite formal and official, there was always a place for us to stay. Sometimes there was transportation to the next village. People were ready for us and Tsvetkova and I did not have to spend several hours explaining what we were doing. Often local officials had identified several people for us to interview. If I compare this to my field experiences in Ukraine where everything was quite freewheeling and where my field partners and I would arrive in a village with no prior notice, no contacts, and no certainty that we would find a place to stay for the night, I can see that the formality of my Kazakhstan arrangements did have its advantages. Even being constantly tracked and monitored had its plus side. In Ukraine I had been taught not to let people know that I was a foreigner. I was told not to register or check in with village officials because that might make the people whom I wanted to interview nervous. The pressure to go unnoticed trained me well and I got very good at blending in and virtually disappearing. This almost led to a real disappearance on one occasion when a couple of thugs in a particularly poor village did discover that I was a foreigner and decided to kidnap me and hold me for ransom. I faced no such dangers in Kazakhstan.

In addition to the bureaucracy and the close monitoring of my activities, there were many other things in Kazakhstan that reminded me of my times in the Soviet Union. One was the lack of consumer goods, especially western ones. There are no McDonalds in Pavlodar, or even the capital Astana. You cannot buy a Coke, though Ukrainian juices and horilka (vodka) were available and the local beer was quite good. There are some imported goods, like clothing and appliances, but most are from neighboring China or the Middle East, with a few things from Europe and nothing from Canada or the United States. The official reason for lack of consumer goods is a policy of protectionism, keeping out foreign products that might compete with Kazakh-produced merchandize in 
order to give the Kazakh economy a chance to grow. There may also be some attempt to keep the local population from knowing about life in the West, much as there was in the Soviet Union. I cannot speak to this because this was not mentioned by anyone. I can say, however, that most television shows featured local or Russian programs. Foreign films dubbed into the local languages, Kazakh or Russian, seemed more scarce than dubbed foreign movies in Russia itself.

While people in Kazakhstan got little chance to learn about life in the West, they could potentially see economic prosperity rivaling that of any Western city right in their own capital. There is a stark contrast between the countryside and the opulence of Astana. Many villages lack roads and one simply drives across the steppe to get to where one is going. Electricity was available in all locations that I visited, but there was no gas except that sold in canisters and there was no plumbing except in a few houses where the owners had installed water pumps. Meanwhile, Astana has gorgeous and literally shining buildings, coated with colored glass to reflect the sun. There are stunning flower beds with flowers planted to look like Kazakh decorative motifs. There are recreation and amusement areas with such frivolous attractions as an indoor wave pool and miniature replicas of world heritage monuments such as the Statue of Liberty. And there is an observation tower from which one can survey the whole glittering panorama. People did not seem to resent the Astana/village contrast. Rather, they seemed to take pride in what had been accomplished in Astana, presumably hoping that improvements would eventually come to villages as well..

Man-made factors are not the sole determinant of life in Kazakhstan. Climate and topography are very important. The land is harsh. The area where I was is flat and gets little rain. Lakes or ponds are few and many of the ones that do exist are salt lakes and not potable; little grows around them. In the summer the temperature can reach forty degrees Celsius or about 100 degrees Fahrenheit; in the winter it can be minus forty a point where the two temperature systems converge. Winds blow with no impediments and are strong enough to virtually knock you off your feet. A particularly fierce storm is the winter buran, a white-out snow storm characterized by horizontally blowing snow. Trees grow only on river banks and in villages where they get some shelter from the wind. Attempts to plant rows of trees as windbreaks, something that was done successfully in the Ukrainian steppe, has, on the Kazakh steppe, produced rows of blackened tree stumps. It is difficult to convey the overwhelming feeling of isolation that one gets in the wide open spaces 
of Kazakhstan. The horizons are endless and the land featureless. But the strongest impression was the feeling of falling off the edge of the world that I got when I reached the end of a village. Inside a village one is surrounded by houses and vegetation. There are streets and animals and people. But when you come to the end of a street, as I did while walking around villages looking for the homes of people I had been told to interview, you are confronted with nothingness. The village ends; the street ends - and there is steppe, just steppe, an endless expanse of brownish, sunburnt grass stretching as far as the eye can see. There are no houses, no trees, no animals - nothing. Sometimes far, far in the distance I could see a black mass - the village cattle herd. Sometimes, closer by, there would be the lone silhouette of a horse on the horizon - a beautiful picture, but one that emphasizes the isolation of the steppe.

Needless to say, this is not an easy place to grow anything. All garden plants such as tomatoes are surrounded by little dams meant to trap the precious few drops of water. The most successful farm products are wheat, cattle, and sheep. The latter are consumed primarily by Kazakhs; the Slavs prefer beef to mutton or lamb. The diet consists of various dough products and meat, which may not sound bad until one has eaten meat, often fatty meat, with various forms of boiled dough and virtually no vegetables for a month. This is a very practical diet. The manty and pilmeni, two forms of dumplings filled with chopped meat, can be cooked for the midday meal and reheated for the evening meal and for breakfast. But it is a very monotonous diet and I had no idea how tasty something like corn or broccoli would seem until I had spent a month in Kazakhstan. There was also a lack of fruits. Villagers did have berries such as strawberries and raspberries in their gardens, but I seemed to be one of the few people interested in eating them raw. Most people saw them as suitable for conversion into jam which would be eaten with the enormous quantities of tea with milk or sour cream that everyone drank.

Kazakhstan is a very large country, the ninth largest in the world, but it is sparsely populated. It has mineral resources and oil and gas, but it is just not that wealthy. Kazakhstan's low population density and its flat landscape, probably along with its remoteness from Moscow and its non-European indigenous population, prompted the Soviet government to select it as the site for its atomic bomb testing program. The area around Semipalatinsk, not that far from Pavlodar, was the location of some 460 nuclear explosions between 1949 and 1989. Nuclear testing has stopped but its legacy lingers. Kazakhstan is still an area where 
pollution is tolerated. In Pavlodar itself there is an aluminum plant with three enormous smoke stacks which constantly spew toxins over the city. Concerns about its health effects surface constantly and time and again the choice between the population's health and economic prosperity is resolved in favor of the latter. As I drove around Kazakhstan, I saw other factories with smokestacks touching the clouds and adding a brown streak to them. I could not help but notice the general ill health of the population, the high blood pressure, the aches and pains, the mobility problems. Was this caused by pollution? It is almost impossible to tell without a systematic study. What I saw could also be the result of lack of health care: medical services, especially in villages, are difficult to obtain.

What was striking was that people had an almost macho approach to the situation. Pollution was one of the many adversities that the harshness of life in Kazakhstan presented and they took a certain pride in facing adversity. The climate was a challenge and pollution was another aspect of the environment that needed to be dealt with and overcome. The attitude toward pollution was analogous to the attitude toward the economy. There was optimism that, now that Kazakhstan was independent, the problems would be solved.

\section{Ukrainian Villages}

The specific villages that I went to are called Ukrainian villages. They were founded by Ukrainians more than one hundred years ago as a result of the Stolypin Reforms. Petr Stolypin, Russia's Agricultural Minister and later Prime Minister, opened up lands such as those located around Pavlodar and encouraged the settlement of peasants by granting private ownership of land. This measure, he hoped, would make capitalists out of farmers and lead them to support tsarist rule. It was the Stolypin Reforms that first brought peasants from Ukraine to Kazakhstan. The stories I heard about the early settlers were tales of courage. I heard about groups of men coming to an essentially barren land and building sod houses, literally carving up the steppe to make dwellings, then bringing their families to join them. The names of the founders were known in most villages and current residents took pride in being descended from them. There were also interesting legends about Stolypin himself. A number of people claimed that he had actually visited their villages once they were officially founded, usually around 1908/1909, and that he had approved of what he saw. Krasilovka a 
village whose name derives from krasa, a word that means beauty, boasted that the name of the village was bestowed by Stolypin himself.

Later migrations of Ukrainians came in the 1930s in response to the Holodomor. Kazakhstan itself experienced a famine at that time, but land was more plentiful and requisitioning efforts not as severe. Russians also came to Kazakhstan, though there does not seem to be a specific period of Russian immigration. A big influx of population came during the Second World War. As Kazakhstan was used for dangerous nuclear tests, so it was also used for people who were deemed dangerous by the Soviet regime, namely ethnic Germans, specifically those that had been living along the Volga. Ukrainian villages were among the recipients of exiled Germans. The last big influx of new settlers came with the Virgin Lands program in the late 1950s and early 60s. In response to Khrushchev's plan to turn the Kazakh steppe into a major grain-producing area, people came from Ukraine, Russia, and elsewhere in the Soviet Union.

The first assumption that I encounter from people in the Diaspora who hear about my trip is that the Ukrainians in Kazakhstan were victims, exiled there by Soviet authorities. Ukrainians, especially people who had converted to Protestant religions associated with Germany, were indeed exiled to Kazakhstan during Soviet times, but they went to areas other than Pavlodar. The people in the villages around Pavlodar were not exiles and not victims; they were anything but that. They saw themselves as brave pioneers, conquerors of a wild frontier. They were people who took charge of their lives. One woman I interviewed in Shcherbakty had been the head of a Ukrainian workers brigade sent to build the grain elevator. She met her future husband and stayed and she was proud of her life and her contribution to the village. The downside to the frontier mentality of the local population is the willingness to tolerate pollution. Otherwise their positive outlook is most heartening.

The villages have experienced new challenges in recent times. When the Soviet Union collapsed, many ethnic Germans left for Germany. Right now large portions of some villages are deserted with collapsed houses or completely empty lots because of German outmigration. Farms, grain elevators, and factories sit idle. As I worked in the various villages to the east and north of Pavlodar, there would be stark contrasts from village to village. The Soviet Union had produced a relatively efficient system of working the land. Family plots were small and the villagers worked in large collectives, seeding huge tracks of land with wheat, barley, buckwheat and even corn. Collectives owned literally thousands of heads of cattle. Land was privatized when Kazakhstan 
became an independent nation. If people took their individual allotments, and especially if there was a loss of population due to the departure of Germans, then the villages struggled. If, however, the collective stayed together, then the villages prospered. This was the case in Orlovka where the village head under the Soviet system, a descendant of the original turn-of-the-century Ukrainian settlers named Poliakov, kept the village together as a corporation in which each resident held a share. In Orlovka the streets are clean and in good repair. The fields are green and not fallow. The village owns 8000 head of cattle, some beef and some dairy, and has worked out an interesting system of letting the herd stay in the steppe and trucking the milkmaids and milking equipment out to the cows. Needless to say, no one has left a place like Orlovka and there are no empty houses. In villages that did not follow Orlovka's example, some people have done relatively well. There has been a shift from keeping large animals such as cows to raising small ones such as fowl. Still, there are people who keep literally hundreds of geese and chickens which they sell for meat. These farmers also have at least a few head of cattle and sell sour cream and butter, the dairy products that keep well. Most villagers, however, have not prospered under privatization unless at least one member has a job outside the family farm such as in the village administration or the village school.

I learned a great deal in Kazakhstan and not just about keeping chickens and separating milk and making little dams to concentrate water on tomato plant roots. I learned about folklore and culture and, comparing what I saw to what I had seen in Canada and Ukraine, I was able to gain the insights into cultural adaptation that I had sought. I think that one of the most important things that I learned is that each geographical region develops its own culture and folklore. The culture and lore cannot be fully explained by the region in which a particular group finds itself though the nature of the region is important and that is why I have given the description above. But climate, geography and contact cultures cannot fully explain what is going on and neither is there a uniform process that occurs whenever a culture moves outside its home. Rather, culture seems to be an entity which takes on a life of its own and develops much like a living organism.

The Ukrainians in Kazakhstan have developed a unique culture. This culture varies from village to village, but there is enough consistency to make it clear that there is a north Kazakhstan Ukrainian culture. The people speak a language that they call khokhlaitsky, a term derived from Khokhol, the Russian slang word for "Ukrainian." This is a 
mixture of Ukrainian and Russian, but it is not the surzhyk Ukrainian/Russian mix found in Ukraine itself. Rituals like weddings also have a mix of Ukrainian and Russian elements, but, like the language, the mix is different from what I have seen elsewhere. The consistency of the mix from village to village made it clear that this was a regional tradition, with variants, of course, but still enough common features to make it identifiable as a local type.

As in Canada, practical considerations play an important role in shaping local ritual. In Canada where one rural priest serves ten to fifteen churches, the Christmas Eve service can be on Christmas Eve, or on Christmas Day, or several days before or after Christmas, depending on when the priest can visit a particular parish. Khram, or Praznik, the special celebration which takes place on the day of the saint after whom a church is named, is often moved to the summer if the particular saint's day falls in winter when country roads make traveling difficult. Provody, the remembrance day for ancestors that should take place a week after Easter, can take place then or well into the summer, many weeks after Easter and sometimes as late as after Pentecost. This tends to be the day when people who have moved away from a village return to visit family gravesites and reconnect with their place of origin. Because this is such a big event, it is often combined with Khram or Praznik and baptisms and weddings are often scheduled for the same day. About the only things which cannot be scheduled to coincide with Provody are funerals. The dominance of practical considerations is understandable in Canada where there is an absence of magical world view and rituals are more a matter of social convention than an attempt to influence the future.

In Kazakhstan a magical world view persists and may be even stronger than in Ukraine, perhaps because of the harsh living conditions. But rituals are governed by practical considerations nonetheless. While Malanka, the New Years Eve celebration has flourished in urban Canada, perhaps because it offers one more party to add to the holiday season, in Kazakhstan the big social event is Maslenitsa, the Shrove celebration before Great Lent. The choice of Maslenitsa is not motivated by the importance of Lent to the local population. In fact, Lent is largely ignored, probably because there are no legumes or other vegetables to substitute for the meat and milk protein that constitutes such an important part of the Kazakhstan diet. Rather, Maslenitsa has come to the fore and become an event celebrated, not just in the home, but in the village center, with officials, school children, in fact most of the village in attendance, because it comes close to coinciding with Navriz, the 
holiday of the New Year celebrated by the Kazakh population. With the emphasis on Kazakh culture that has come with independence and the new, Kazakh-led regime, celebrating a Ukrainian holiday that can be combined with one that is part of the dominant culture is a good way to promote one's own.

Kazakhstan does not have the practice of assigning one priest to serve a circuit of churches and, as a result, many villages have no church and no clergy person. The practical solution to this situation is for villagers to perform various rites themselves, including important religious ones such as baptism. Weddings can be performed with no clergy present. They are then officially registered to meet bureaucratic demands. Registration can occur before the wedding, as in Ukraine, or it can occur after the wedding, sometimes long after the wedding. It does not seem to matter as long as the ritual itself, the folk aspect of the wedding, is performed. Perhaps the most striking practical performance of a ritual act comes at Iordan, or Kreshchenie, usually called Epiphany in the West. Water is blessed in church on this day and people take it home to use for illness. They use it to bless the house and the cattle and keep it for any situation where a little divine help is necessary. With no village church, there is no place to get water blessed on Epiphany. The solution to this problem is very simple. People go out to the well on the eve of Epiphany and draw water which they sincerely believe has magical properties. Any number of people, both villagers and urban dwellers, swore that the water was special and had magical and healing powers. As evidence they pointed out that Epiphany water, unlike regular water, would not spoil: there was never any trace of sediment or algae. Some people said that simply drawing water on the eve of January 19 was not enough and that special actions needed to be taken. These included drawing water at a certain time, usually midnight, though 4AM and 6AM were also mentioned. Some people said that the water needed to be left outside for several hours so that the light of the moon and the stars could shine on it and confer the power of the heavens. A very few said that water either needed to be drawn at the time that a church service would normally take place or that it needed to be set out at that time. The belief in the magical properties of Epiphany water was remarkably widespread. I found it among religious people and those who were not religious but had the magical world view we often associate with the folk, especially those living in villages. I also found it in the city. A very sophisticated and educated city dweller and an avowed atheist also swore by the power of Epiphany water and gave me a number of other 
instances where he had observed the intervention of the supernatural into his life. We cannot make neat categories and state that a magical world view is characteristic of uneducated country folk only.

A similar combination of the practical and the magical can be found in the area of folk medicine. Folk medicine includes, in addition to holy water, various herbs and tinctures made from them. Physical manipulation, bone-setting included, falls in this category. There is also wide-spread use of charms and magic actions such as rinsing the face of a colicky baby with dirty dishwater and wiping it with the inside of one's apron or skirt. Some of these charms or actions need to be performed by a specialist, but many do not. In fact, in the absence of specialists, people write down charms and instructions for performing actions and say the charms and perform the magical actions themselves. Cures are used to relieve human suffering and are also widely applied to farm animals, especially cattle, which is quite understandable considering the importance of cattle to the local economy. In Kazakhstan, people were not reluctant to talk about resorting to various magical practices; they showed me their books of charms and let me photograph them. To them, this was just something that was done and not really anything special. This is quite different from the situation that I found in Ukraine where magic practices, charms and magical actions among them, abounded, but were hidden from view. People were reluctant to admit to knowledge of magic in Ukraine, but not in Kazakhstan. This is possibly the result of more extensive persecution of behavior that would be deemed superstitious and thus un-Soviet in Ukraine, a country closer to the Soviet heartland than the remote areas around Pavlodar. The contrast between Ukraine and Kazakhstan is also quite curious and needs further investigation since people in Kazakhstan attributed the source of their magical knowledge to Ukraine and, indeed, the notebooks that they showed me with charms and instructions for performing magical curative acts were written in Ukrainian, not khokhliatsky.

People took magic seriously in Kazakhstan and they fully believed in the efficacy of ritual acts. At the same time they viewed rituals as fun occasions, a chance to have a good time.

The ritual elements that are most consistent between Ukraine, Canada, and Kazakhstan are not the solemn ones, the ones that seal the bond of matrimony, for example. Instead what people remember and what persists from country to country are carnivalesque elements such as cross-dressing at weddings. In all three places the solemn part of the wedding is followed by a mock wedding with a humorous mock bride 
and groom. Who gets dressed up as the fake and funny couple varies, but some sort of costuming, complete with feasting, often on stolen food, is a regular feature. People felt that weddings were important and solemn occasions, but they did not feel that they had to be solemn throughout the ritual process. Lack of consistency did not bother anyone and even some destructive behavior, such as stealing chickens and scratching up the walls of the groom's house, was tolerated. Comic and destructive elements are found not only in weddings but also in calendar rituals such as Christmas and Maslenitsa/Shrove. People even talked about the necessity of joking at funerals to entertain the deceased and stated that this was especially important while washing the body. A serious approach to ritual does not preclude levity.

Throughout my professional career I have sought to understand why folklore persists. Travelling through a number of villages fairly quickly as I did on this trip it became obvious that folklore is necessary for wellbeing. Perhaps the benefits of folklore stood out with special clarity against the harsh natural and political environment of Kazakhstan, but they were impossible to ignore. Those villages in which people actively engage in various forms of folklore turned out to be much more cheerful and friendly. In some villages no one does embroidery and the only embroidered objects were heirlooms made by mothers or grandmothers. When I asked about embroidery, people said that it was a thing of the past and that the old items, many of which were indeed treasured, did not really fit in the home any more. As a result, they gave them to local museums. In Rozhdestvenka, inspired by an elderly and locally born resident named Klavdia Tereshyna and a woman who had moved to the village from Ukraine named Evheniia Bikotserkivets, everyone embroiders. They do some embroidery of the traditional type on ritual towels called rushnyky and they do rushnyk designs on pillow cushions and runners. They also do a very modern adaptation of needlework, namely embroidered pictures. Many pictures show scenes reflecting life in Ukraine, or Ukrainian life as the artists image it to be, but most pictures have modern and area-specific motifs such as local flowers and even a mosque. The women in Rozhdestvenka are also remarkably cheerful. Their village is not super-prosperous like Orlovka and neither is it run-down like Krasilovka. But the women are noticeably happier than women who do not engage in crafts. I should note that, in northern Alberta, women with a similar disposition are also embroiderers or weavers or people who enjoy another craft such as crochet and the embroiderers also make pictures, often featuring Canadian scenes. 
Embroidery is only one of the folklore forms that leads to spiritual and physical well-being. In several villages there are groups that get together to sing. Some of these groups are formally organized by a local official such as the Dom Kul'tury (House of Culture) worker. The formal groups get together to sing for personal enjoyment. They also perform at various holidays and other community events where they not only sing, but showcase crafts and foods, and engage in competitions akin to bakeoffs. Some groups get together informally. In Khmelnitskoe, a group of widows gathers to sing and chat. We joined them for a birthday celebration that featured food, drink, and plenty of singing. Both formal and informal groups tend to be multi-ethnic. In the case of services provided by a village official, multi-culturalism is a government mandate. But informal groups are also inclusive. The one in Khmelnitskoe is predominantly Ukrainian, but also has two Russian members and a Kazakh. The songs they sing are also predominantly Ukrainian, though all members know and perform Russian and Kazakh songs as well. Maintaining ethnic purity, so frequently a concern in Ukrainian Diaspora groups both in Canada and the United States is just not a concern here. In fact, it was not a concern in rural Alberta and people made or sang what appealed to them, regardless of its ethnic origin. Ethnic purity, like maintaining solemnity during rituals or differentiating the magical from the scientific is not important.

That being said, Ukrainian culture did dominate in many ways. Alevtina Tsvetkova, an ethnic Russian herself, said that it was because Ukrainians prize their culture more than other ethnic groups. Other reasons might be that Ukrainians outnumber other nationalities in the villages that I visited or that they, as village founders, have established their culture more firmly. In any case, there are more Ukrainian clubs in various villages, more singing groups that dress in Ukrainian costume (or what they think is Ukrainian costume) when they perform. Perhaps the most striking attestation of this fact were old photographs of weddings. In my effort to get a sense of the history of ritual practice, I asked not only about contemporary rituals, but about rituals as they were celebrated in the past. I also asked to see old photographs and rephotographed whenever I could. In Kovalevka we were interviewing an elderly Ukrainian woman whose daughter had married one of the local Germans and moved to Germany when the Soviet Union collapsed. The younger couple had come back from Germany to visit. I asked about weddings and the man who now lived in Germany, spoke German, and had the very German name of Jacob Blok, showed the wedding photographs of 
his older sisters. They were wearing white dresses, but on their heads were very Ukrainian-looking wreaths, complete with ribbons. The weddings had taken place in Kovalevka and the family, while maintaining their German identity, saw no problem with adopting Ukrainian wedding wreaths.

There are ethnic tensions in Kazakhstan. While this country was under Soviet domination, everyone resented the Russians because it was they who got the best jobs, the best schooling, the nicest living quarters. Now that Kazakhstan is independent and ruled by an ethnic Kazakh, albeit one who was Communist Party head prior to independence, everyone who is not a Kazakh resents the Kazakhs. Virtually every village akim that I met and all district akims were Kazakhs. The police officers were Kazakhs. The officials at the border when I flew in were all Kazakhs. But resentment against any nationality exists in the abstract only. Just as Kazakhs helped Ukrainians when they first came to settle in this land, so now individual Kazakhs and Ukrainians and Russians and Germans are on the best of terms. In Uspenka a Ukrainian family whom I interviewed had Kazakh neighbors and the little Kazakh child living next door not only regularly played at the home of the Ukrainian couple, but called them baba and dido, the Ukrainian words for grandma and grandpa. I stayed with Kazakh families as well as with Ukrainian ones. There are legends about the past which blame the Kazakhs for plugging up springs with felt and thus depriving the area of water. But the legends voice precisely the general and abstract hostility that people feel. Concrete individuals are honored and cherished, regardless of nationality.

And this report would not be complete without the mention of at least a few of the many moving individual stories that I heard. I talked to a couple both of whom had tragically lost their spouses and descended into depression, but then found each other and recovery and happiness. I talked to several couples who had been together all their long lives and shared their enthusiasm for Ukrainian song and other folk arts. There was a man who had become an alcoholic and whose wife and children left him. He had recovered with the help of his mother and music and now kept his mother's house, which was immaculate and played the accordion while his mother played guitar.

I am truly lucky that people will allow me into their lives and talk to me and share their arts. When we went to Uspenka, the otherwise careful planning of my various trips failed and we were not expected when we arrived. At first the village akim, one of the few officials who was an 


\section{REPORTS}

ethnic Ukrainian, was quite hostile. But when I started interviewing some of the local residents, the akim and the other villagers whom he had summoned decided that what we were doing was actually quite interesting - they were able to learn about themselves as well as help me learn. As a result, the akim offered to have us move into his home and drove us all over everywhere, actually not giving me as much of an opportunity to stretch my legs as I would have liked. Again, I am most fortunate that I have an occupation that is useful to others. It allows me to travel and to learn. And incidents like the one in Uspenka reassure me that I am not just getting something from the people I talk to, but giving something back. This essay is just the first of what I hope will be a number of pieces about Kazakhstan. I hope that the people I talked to as well as the readers of these words benefit from my observations and my work. 


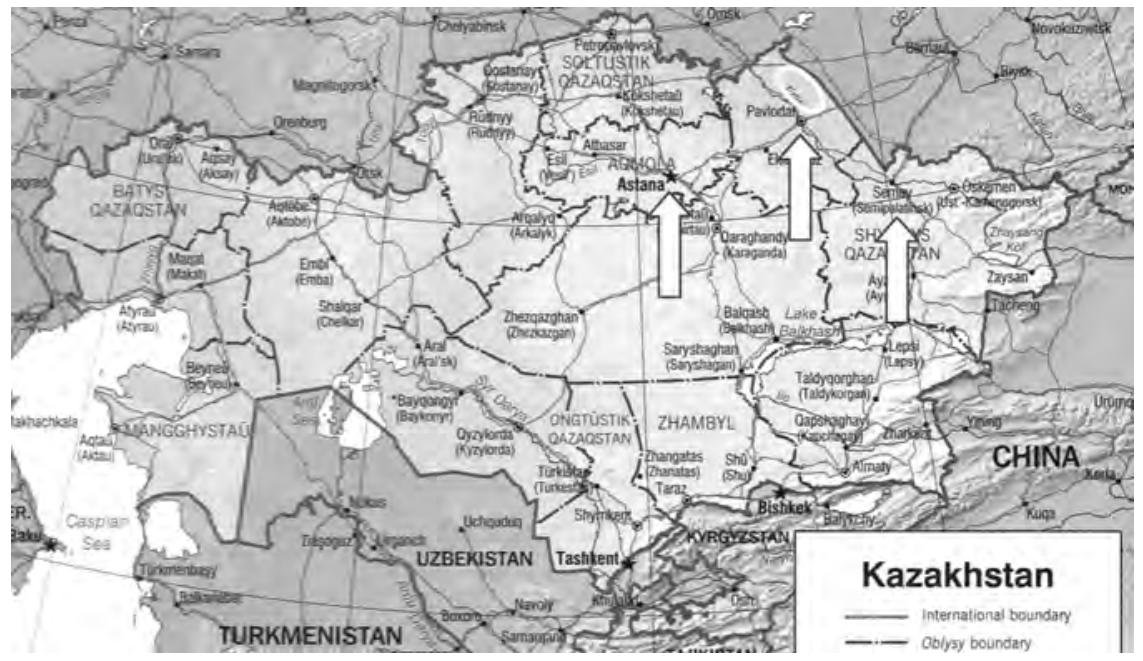

Map of Kazakhstan. The three arrows point to Astana, Pavlodar and Semipalatinsk. The area I visited is the white oval above Pavlodar.

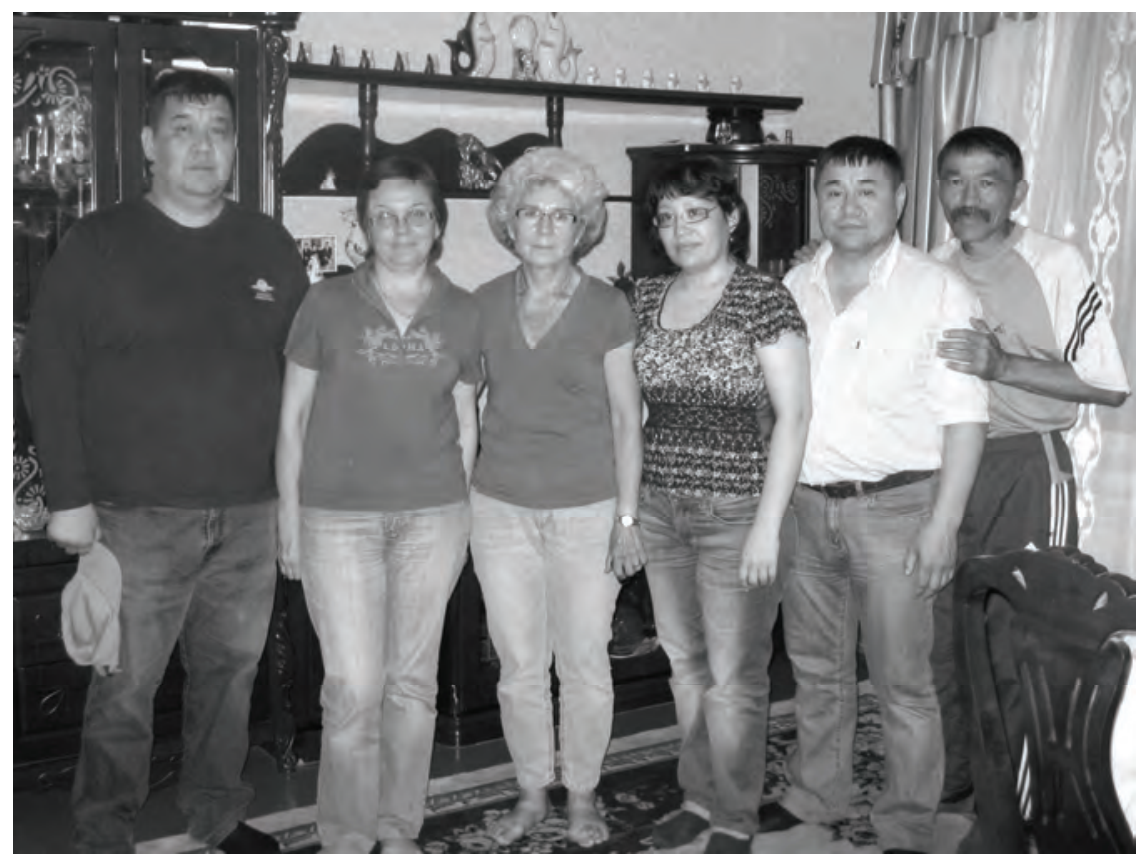

Alevtina Tsvetkova, on my right, with the Kazakh family with whom we stayed in Khmelnitskoe 


\section{REPORTS}

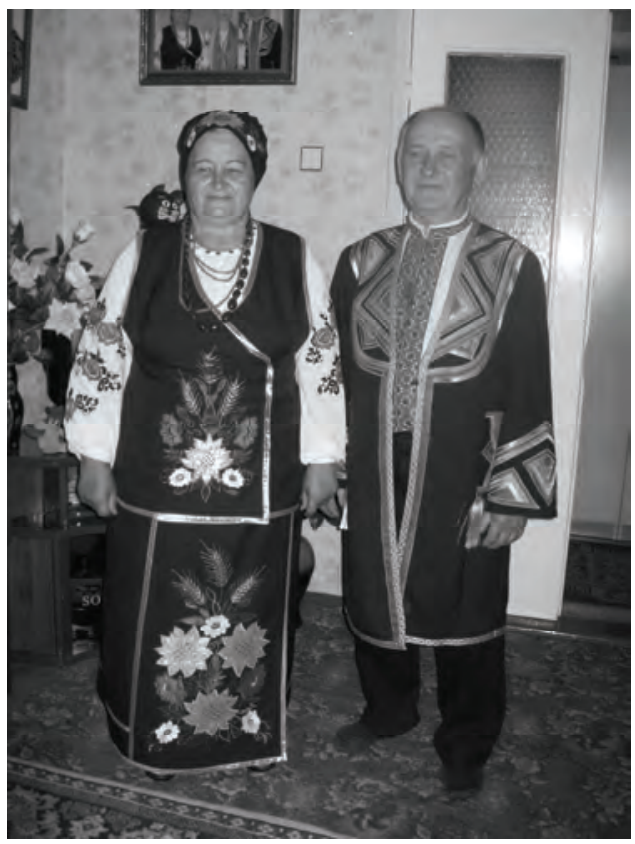

Petro Maslii and his wife Antonina, members of a folk song group in Pavlodar

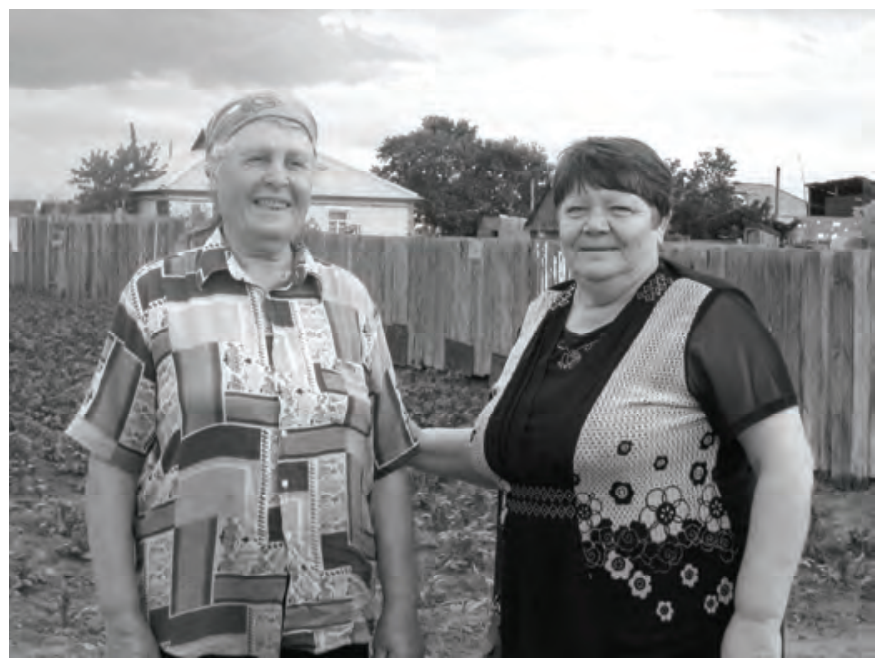

Taisiia Lytvynenko, on the left, who came as a builder to Shcherbakty standing with Evheniia Rybalka, the head of the culture organization. 


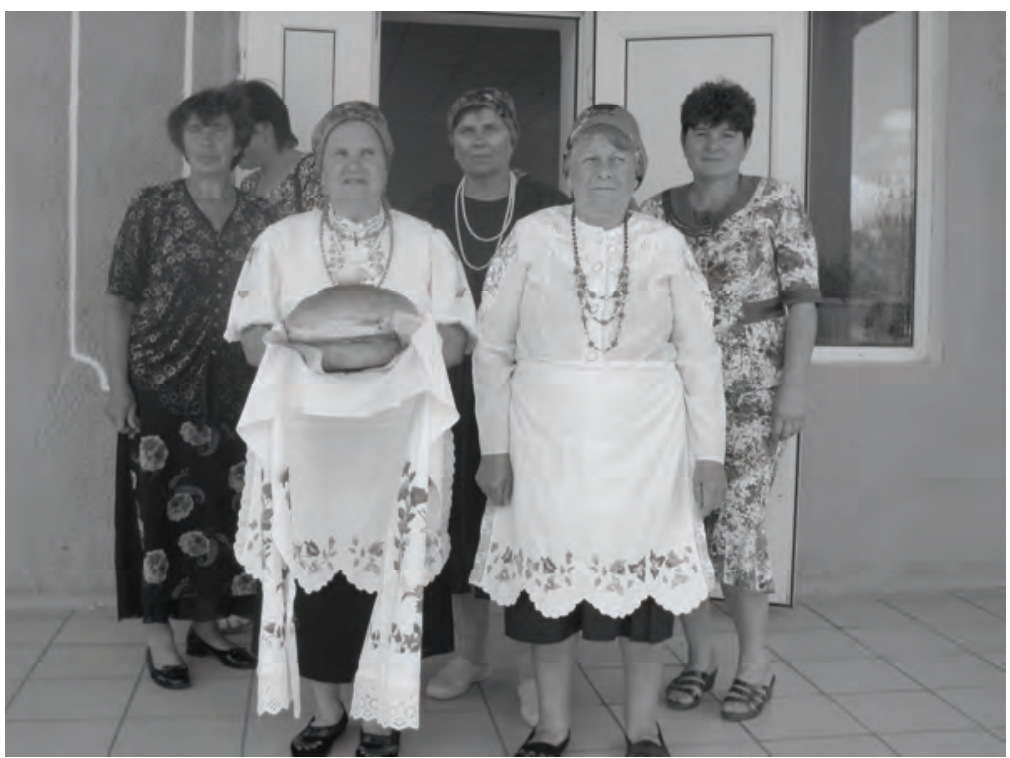

The local culture club welcomes us with bread and salt in Krasilovka

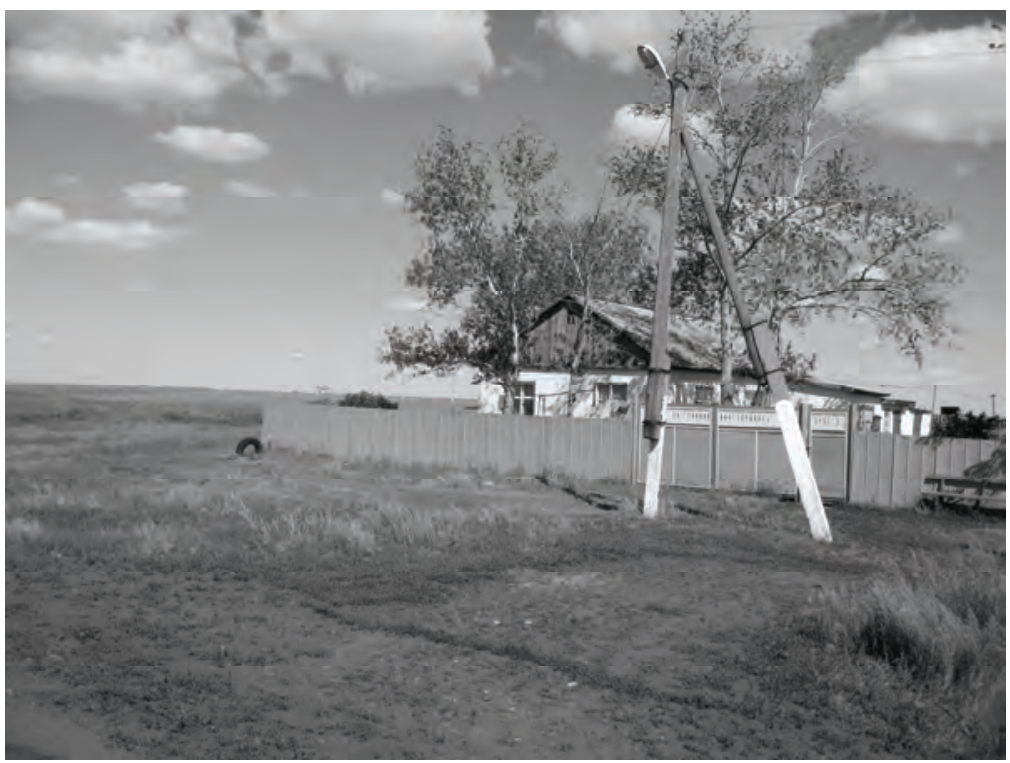

The edge of the village Kovalevka 
REPORTS

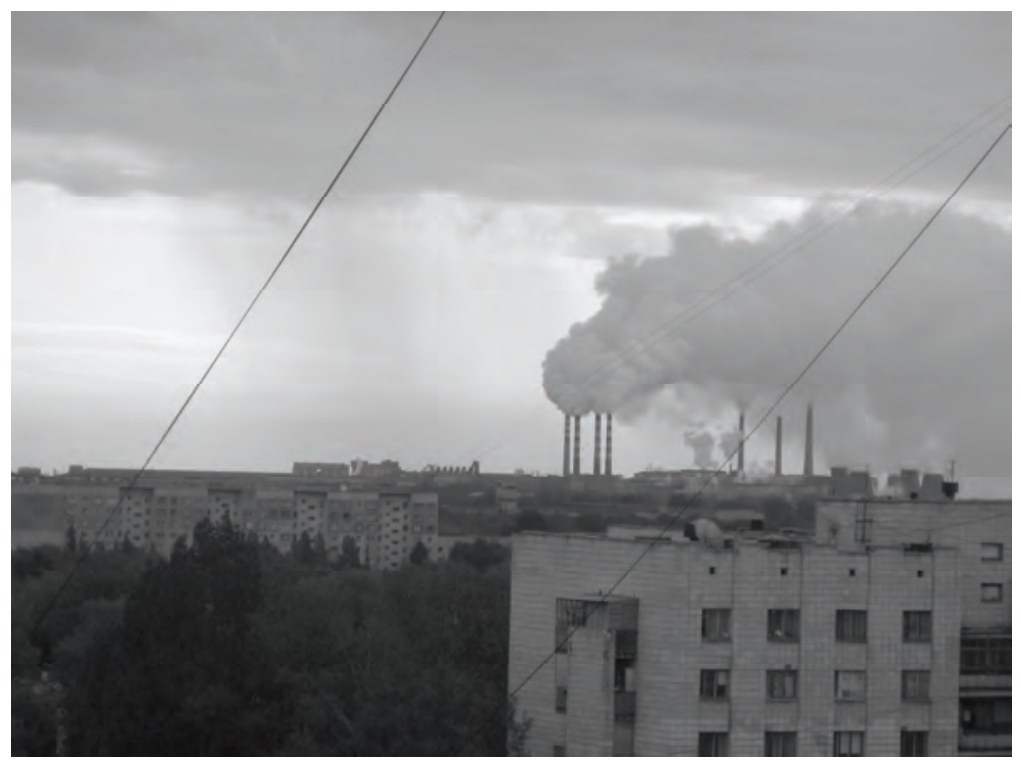

Aluminum factory in Pavlodar

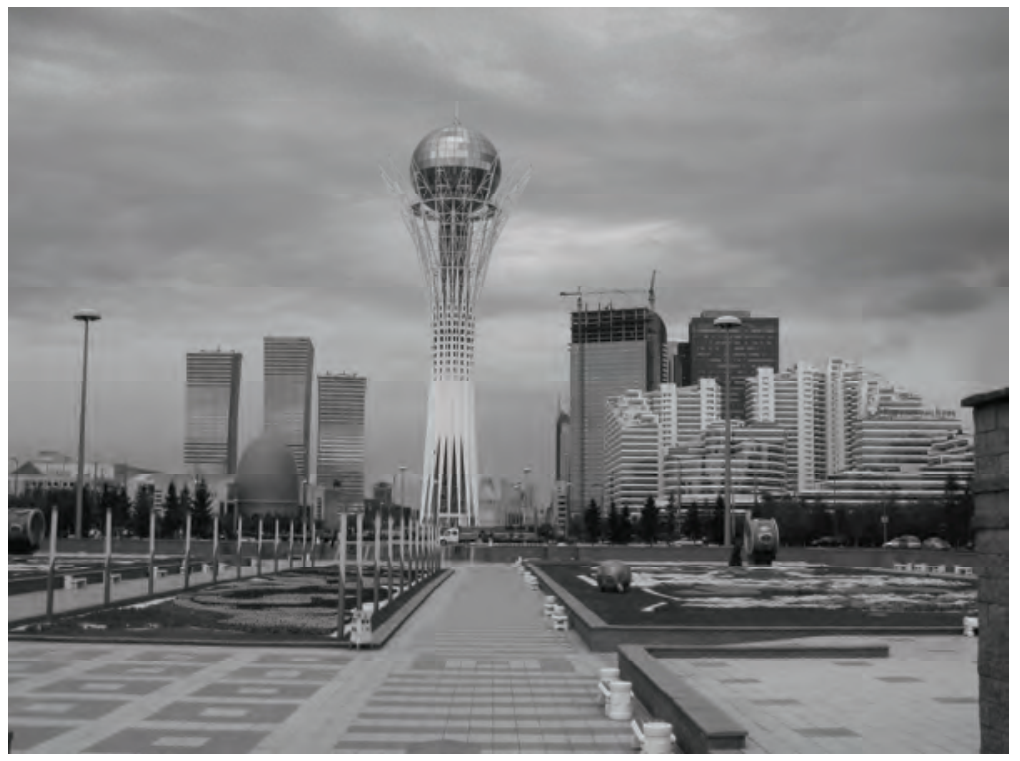

Astana: Bay Terek, the observation tower is in the middle 